\title{
Les Barattes de Cafer (Malatya, Turquie) : Contribution ethnographique à l'étude du mobilier archéologique
}

olivier Aurenche

\author{
(2) OpenEdition \\ Journals \\ Édition électronique \\ URL : https://journals.openedition.org/tc/887 \\ DOI : $10.4000 /$ tc. 887 \\ ISSN : 1952-420X \\ Éditeur \\ Éditions de l'EHESS
}

Édition imprimée

Date de publication : 1 février 1987

ISSN : 0248-6016

Référence électronique

olivier Aurenche, « Les Barattes de Cafer (Malatya, Turquie) : Contribution ethnographique à l'étude du mobilier archéologique », Techniques \& Culture [En ligne], 8 | 1987, mis en ligne le 23 janvier 2006, consulté le 29 septembre 2022. URL : http://journals.openedition.org/tc/887 ; DOI : https://doi.org/ $10.4000 /$ tc. 887

Ce document a été généré automatiquement le 29 septembre 2022.

Tous droits réservés 
Les Barattes de Cafer (Malatya, Turquie) : Contribution ethnographique à l'étude du mobilier archéologique

olivier Aurenche 